\title{
Promoting transit oriented development typology in the transportation planning
}

\author{
Herika Muhamad Taki ${ }^{\mathrm{a}, \mathrm{b}^{*}}$, Mohamed Mahmoud H. Maatouk ${ }^{\mathrm{a}, \mathrm{c}}$ \\ ${ }^{a}$ Department of Urban and Regional Planning, FED, King Abdulaziz University, Jeddah, 21589, Saudi Arabia \\ ${ }^{b}$ Department of Geography, FMNS, University of Indonesia, Depok, 16424, Indonesia \\ ${ }^{c}$ Department of Architecture, FE, Minia University, Minia, 11432, Egypt
}

Article history:

Received: 17 November 2018 / Received in revised form: 29 November 2018 / Accepted: 30 November 2018

\begin{abstract}
The provision of rail-based public transport such as railways in the many cities of the world has experienced progress providing the best service to the community. However, there are a few problems along with these advancements, such as the ineffectiveness of modes and networks as well as the inefficiencies of time and cost. Therefore, this paper aims to promote the application of Transit-Oriented Development (TOD) based on typology from existing stations in the Jakarta Metropolitan Region (JMR), Indonesia. It is expected to be able to create a public transport system that is integrated with the needs of the community. It makes easy access to achieve their travel destinations. This paper uses spatial analysis to determine the various TOD typology by involving many variables and indicators. It also creates a spatial model and applies it to transport planning in the JMR. The results obtained are three typologies of TOD namely Regional, Urban and Suburban. All types of TOD scattered in JMR and it has a trend pattern. TOD Regional located in the central core of the JMR, Urban TOD in the center and suburban TOD outside the center. This study is very helpful in guide transportation planning where several stations and railways intersect with future projects such as LRT, MRT, and BRT. It is expected to improve an integrated and sustainable transport planning.
\end{abstract}

Keywords: Transit Oriented Development (TOD); transportation planning; Jakarta Metropolitan Region (JMR).

\section{Introduction}

Land use and transportation are the key actors to urban planning [1]. The well-regulated city is characterized by the conditions of land use and transportation systems and it indicates economic prosperity [2]. However, there is a tendency that the city development is followed by the various issues of transportation and land use [3]. These issues include traffic congestion, energy wastage, delayed travel time, air and sound pollution [4]. This is a complex problem that involves many aspects and interrelated. Thereby, many researches were conducted to pursue the solution of these issues. Most previous studies examine the application of TOD in Indonesian cities [5]. However, lack of studies has been conducted that discussing the typology of TOD at the urban or regional level, besides that the study has not yet integrated transportation and spatial planning. Therefore, this paper introduces an integrated TOD as the spatial model to guide transport planning.

The population of the Jakarta Metropolitan Region (JMR) continues to increase, and this region experience growth with the distribution of development in suburban settlements [6]. While the capital city of Jakarta acts as a trade, business center, and social communication. Suburban areas continue to grow, the number of commuters from suburban to Jakarta will

\footnotetext{
* Corresponding author.
}

Email: htaki0001@stu.kau.edu.sa increase. For this reason, it is important to shed light on the transportation planning of JMR before introducing the implementation of the integrated TOD based on the spatial model.

A railway system of Jakarta Metropolitan Region services Jakarta, Bogor, Depok, Tangerang, and Bekasi. The rail system uses rapid transit rolling stock standard and operates at high frequency with a minimum headway. The network route is recognized by Fig. 1 and Table 1 .

Most people living in JMR use motorcycles and cars for daily commutes to and from work, causing severe traffic jams in the capital city during rush hours. Based on study of [7], it was stated that the forecast demand for total trips and modal share per day in 2020 becomes 36.578 million trips/day and in 2030 becomes 38.070 million trips/day (Table 2).

To accommodate many commuters, it needed the development of transportation facilities with an emphasis on the development of the mass public transport system [8]. The transportation modes in JMR will not be able to accommodate increased travel demand if without an increased mass transportation system for the public.

The transportation master plan of JMR in Fig. 2 is directed to the development of a rapid mass transportation systems until 2030, including LRT (Light Rapid Transit) and MRT (Mass Rapid Transit), the development of a cross-regional road and toll road network system. In addition, revitalization of 
commuter line, providing park and ride facilities and implementation of TOD in areas with high density.

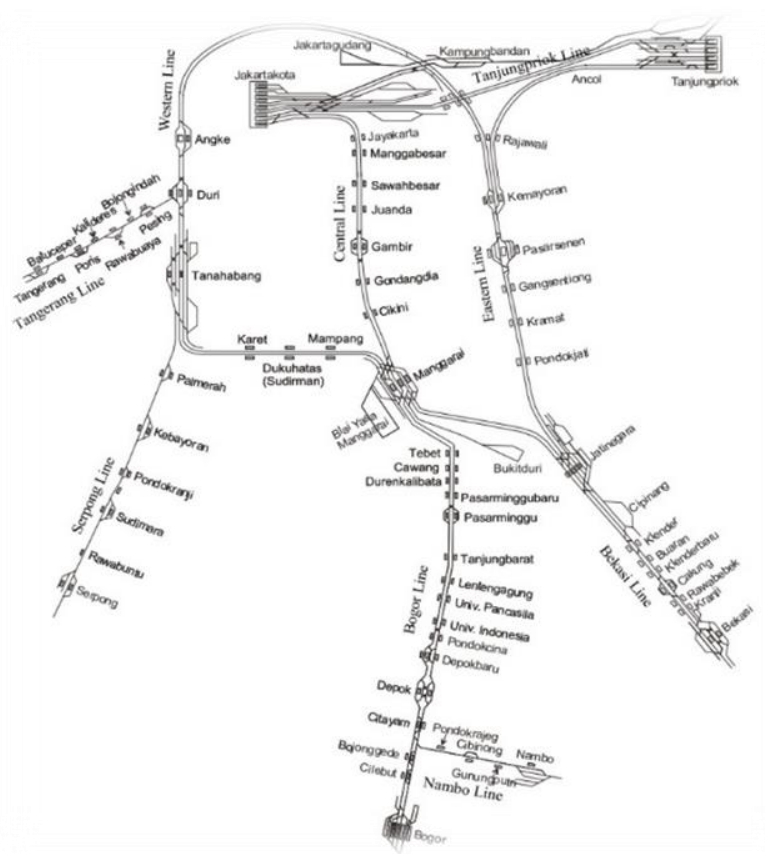

Fig. 1. Railway route of JMR

Table 1. The existing conditions of JMR's railway

\begin{tabular}{llcl}
\hline \multicolumn{1}{c}{ Lines } & \multicolumn{1}{c}{ Services } & Stations & Length \\
\hline Bogor & Kota to Bogor & 26 & $54.8 \mathrm{~km}$ \\
Serpong & TA to Serpong & 7 & $55.6 \mathrm{~km}$ \\
Bekasi & Kota to Bekasi & 13 & $26.5 \mathrm{~km}$ \\
Tangerang & Duri to Tangerang & 8 & $19.2 \mathrm{~km}$ \\
\hline
\end{tabular}

Table 2 Demand forecast for trips per day in JMR. Source: [7]

\begin{tabular}{lcc}
\hline \multirow{2}{*}{ Mode } & \multicolumn{2}{c}{ Year } \\
\cline { 2 - 3 } Private car & 2020 & 2030 \\
\hline share & 11.555 .550 & 11.231 .034 \\
Motorcycle & $31,6 \%$ & $29,5 \%$ \\
share & 6.643 .196 & 6.420 .147 \\
Bus & $18,2 \%$ & $16,9 \%$ \\
share & 16.093 .555 & 15.079 .101 \\
Rail & $44,0 \%$ & $39,6 \%$ \\
share & 2.286 .369 & 5.340 .483 \\
Total & $6,3 \%$ & $14,0 \%$ \\
& 36.578 .671 & 38.070 .766 \\
\hline
\end{tabular}

Improving public transport services will encourage a decrease in the usage of private vehicles and contribute to reducing traffic congestion, decreasing air pollution and noise and increasing transport safety [9]. The main policy of developing a transportation system of JMR is to support interregional transportation needs, the development of urban corridors, strengthening access, and developing the road system.

\section{Materials and Methods}

The data in this paper is spatial and attributes data (Table 3). The collected data are obtained from agencies, ministry, and previous researches. It can be expected to support the process in this study.

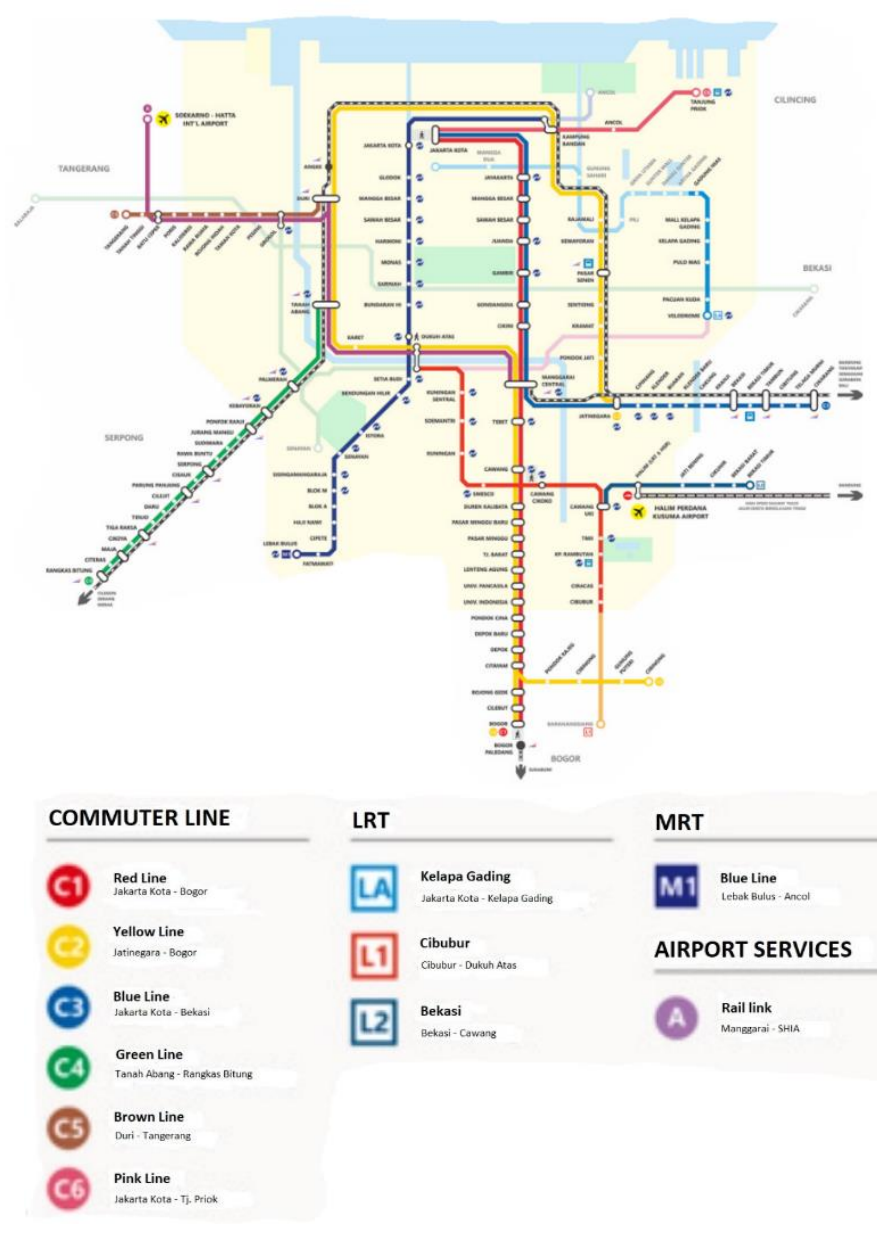

Fig. 2. Railway route of JMR

Table 3. List of datasets

\begin{tabular}{lll}
\hline \multicolumn{1}{c}{ Datasets } & \multicolumn{1}{c}{ Source } & Year \\
\hline Study area & GIS Agency & 2015 \\
Spatial plan & GIS Agency & 2014 \\
Transportation plan & Ministry of Transportation & 2015 \\
Actual TOD & Previous research & 2017 \\
Potential TOD & Previous research & 2017 \\
\hline
\end{tabular}

The methodology was done by studying the literature about the concept of TOD, land use, and transportation, collecting and analyzing spatial and non-spatial data. The finding of this paper is obtained by creating an integrated TOD by combining actual and potential TOD, differentiating TOD based on typology, afterward implementing the integrated TOD spatial model to guide transport planning (Fig. 3).

\section{Results and Discussion}

\subsection{Spatial Planning Equipped by Potential TOD}

The transport network pattern of JMR is the radial system and spatial form is the multinucleated urban structure with corridors and nodes. It means that the intense land uses in this structure are extended out from the CBD along major transportation routes. [10] promote to the placement of TOD on that location with the proposal like the Fig. 4. Placement of stations and railways right on the hub and passing the entire 
main cities of this region.

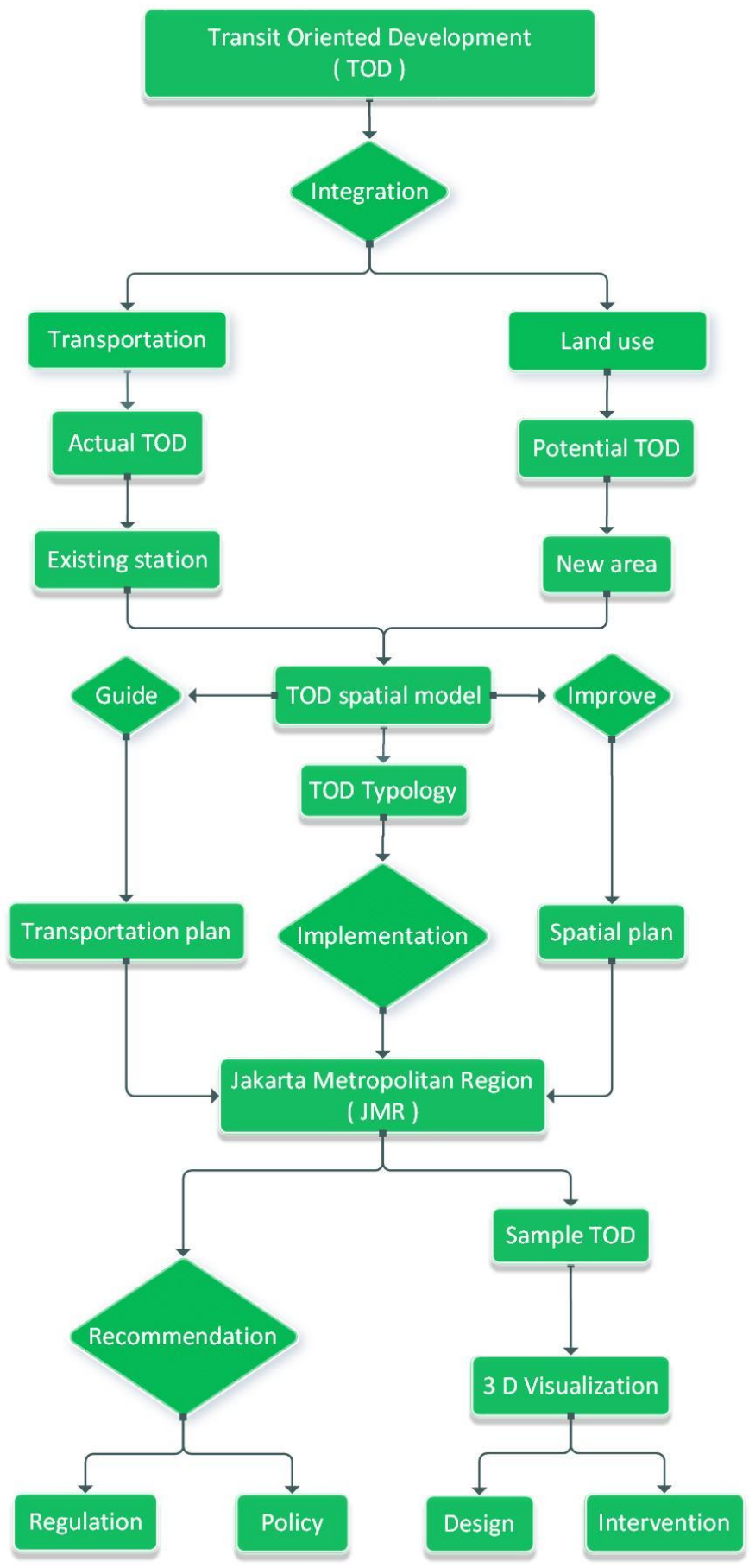

Fig. 3. Conceptual framework

The development proposal of BRT, LRT, and MRT with TOD is designed to cover the entire JMR area by looking at physical conditions of land use and available road network. Improvisation of this public transport connecting sub-urban and urban areas between Jakarta and surrounding area, with good ties is expected to create solutions from various issues that occur such as congestion and environmental pollution.

This proposal is only a general design without measuring in detail and determining the type of TOD at the station. Therefore, further in-depth research is needed to find out what type of TOD is suitable to be placed at each existing station in the transportation network system, as well as determine which potential areas for new TOD placement in the urban structure.

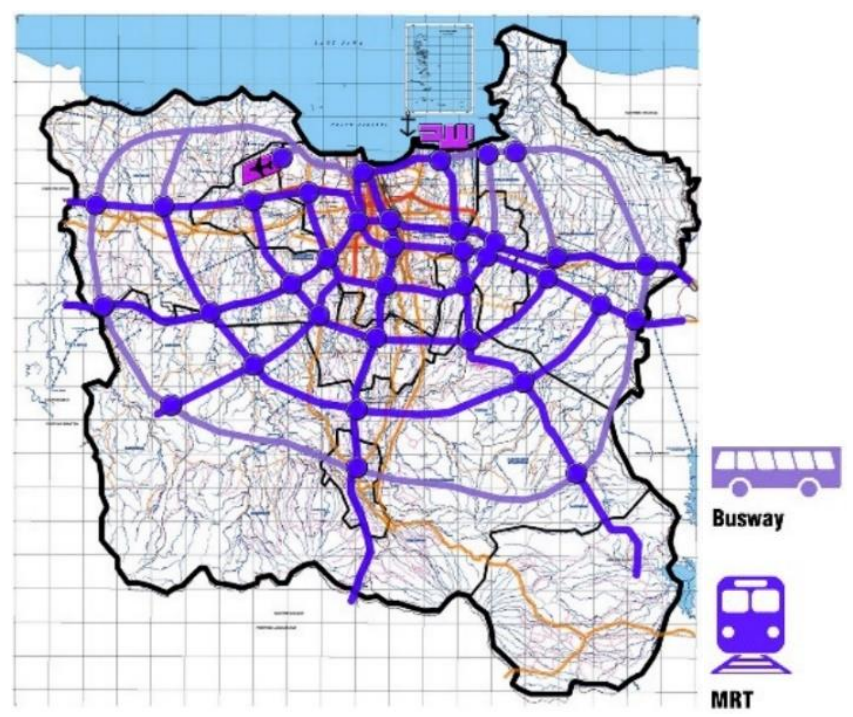

Fig. 4. Public transport network plan. Source [10]

Referring to the spatial pattern of JMR previously mentioned, in the upstream area with strong conservation function, space allocation should be dominated by a kind of protection.

In mid-stream can be proportioned the allocation of space that may function for economic, social, and environmental activities. Space allocation of economic activity in this section can be wet or dry agriculture, plantation, shops, and trade, as well as limited and non-pollutant industries.

The dominance in the downstream is for settlement activity and the dominant economic activity, but still, pay attention to green open space in macro area. Economic activities in the downstream area can function as dense residential on the scale of economic activity in residential, shops, large and small industries, malls, services and trade. Referring to the above exposure, the suitable location for TOD is in the mid and downstream areas. Placement of TOD at this location not only support transport and spatial dynamic by time but also consider the environmental balance.

\subsection{TOD Typology}

TOD typology is done by grouping transit areas according to existing conditions so that it is useful to identify potential TOD. [11] introduced the TOD typology into Urban and Neighbourhood TOD, then the typology was developed by various subsequent studies such as [12-14]. [15] proposed the TOD typology called TOD Regional Center, Urban Center TOD, TOD Suburban Center and Transit-Town TOD. In this Chapter, TOD typology is limited to Regional, Urban and Suburban TOD with the following explanation:

Regional TOD is regional service centers, it is the center of economic activity and regional community. This TOD creates synergy between the community and the region, between work and settlement, between the level of density and service, between individuals and society. [16] identified the TOD Regional with the presence of thematic land-use mix, with the 
dominance of the building environment served by various modes of transportation in a network. Fig. 5 illustrates 3D visualization of the Regional TOD

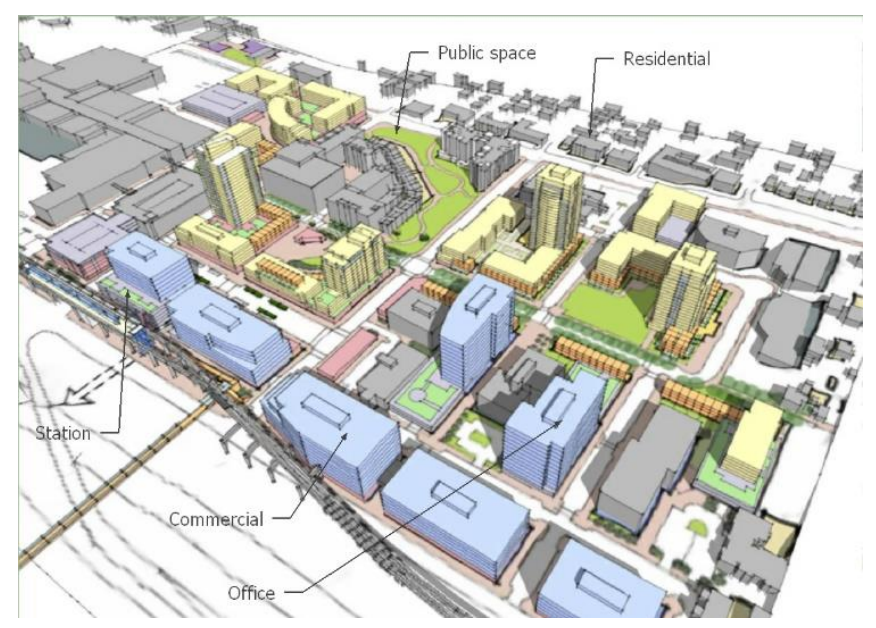

Fig. 5. 3D visualization of Regional TOD

Urban TOD is the city service scale, it is the character of urban development as the primary functioning economic center in the main circulation path of the city such as intercity bus stops and train stations both light rail and heavy rail (Fig. 6). Urban TOD was developed in conjunction with commercial functions that have high intensity, office blocks, and highdensity dwellings. The TOD plan focuses on high density settlements because it allows direct access to transit points without having to change other modes.

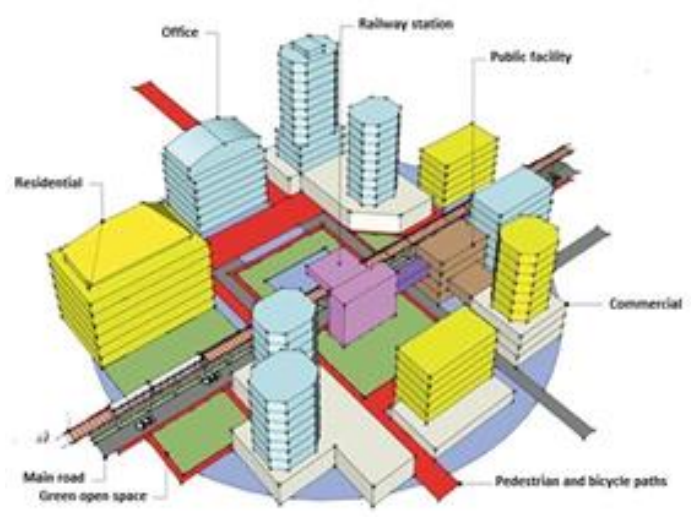

Fig. 6. 3D visualization of Urban TOD

Suburban TOD is the sub-city center, it services local residence and helps the development of housing for the lowand middle-income class. Suburban TOD is equipped with public facilities and green open spaces, so it provides easy access using various modes (Fig. 7).

\subsection{Producing TOD Typology Based on the Spatial Model for $J M R$}

JMR is a metropolitan region of several surrounding cities with its centre in Jakarta capital city. Railways in study area crossed several cities including Tangerang city, Depok city, Bekasi city and Bogor city. The primary road is the main access in this region besides railway access. The primary road network connects between centres or regional activities. Therefore, the role of TOD in this case as transit and service centres in residential areas is equipped with good service infrastructure facilities. TOD of JMR is very helpful in the city and region development because it becomes a spatial model to overcome urban sprawl that is the expansion of urban activities in the suburbs with irregular patterns, the impact of the migration of some residents of high density from urban areas to suburban.

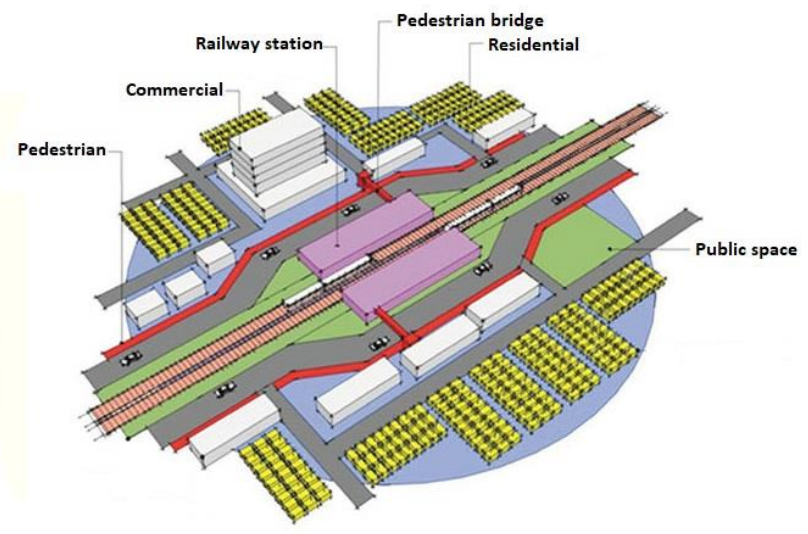

Fig. 7. 3D visualization for Suburban TOD

The development pattern of JMR has strongly affected the mobility of the population from suburban to urban, namely increasing the traffic frequency on the primary road and railway. Hence, TOD planning should consider transit location, primary transit network, secondary feeder transit and supporting facilities. Thus, land use will be integrated into the road network and public transportation modes.

The data analysis derived from combined actual and potential TOD produces an integrated map of TOD in JMR. The method used for the analysis is multicriteria analysis to get actual TOD and the land suitability evaluation method to get potential TOD. Both methods are supported by AHP techniques to gain priority criteria values and GIS applications to explain spatial in the Table 4.

Actual TOD index means an assessment of the existing station and related to transportation aspect [17]. The unit of analysis explained by index is based on the node of the train station location. The method used in this paper is a spatial analysis technique. The tools used are GIS application to display the resulting map obtained (Fig. 8).

The planning of potential TOD in Fig. 8 means a potential location for the new station and it relates to the spatial aspect. The method used is the land suitability evaluation method involving 20 criteria to obtain a very potential area for developing a new station. The method in this paper is done in more detail by using spatial statistical analysis technique for getting the hotspot area which is very significant for a new TOD station [8]. The results obtained are many clusters of hotspots in the urban center (Jakarta downtown) and few in surrounding areas (Tangerang, Depok, and Bogor).

Fig. 9 shows a station typology of TOD based on actual and potential. This typology is found in the administrative area of JMR. The figure describes TOD implementation in JMR based on its typology. Each type is taken one example of a station that represents other stations of the same type, this scenario can be 
used as a model by the government and related parties. Each type is represented by samples such as Sudirman station for Regional TOD, Depok station for Urban TOD and Bojonggede station for Suburban TOD.

Table 4. TOD typology by index

\begin{tabular}{|c|c|c|c|c|c|c|c|c|c|c|c|c|c|c|}
\hline $\begin{array}{l}\text { Criteria } \\
\text { Weight }\end{array}$ & & & $\begin{array}{c}\text { Density } \\
0.51 \\
\end{array}$ & & & & & & \multicolumn{3}{|c|}{$\begin{array}{c}\text { Economic } \\
0.27\end{array}$} & \multirow{2}{*}{$\begin{array}{c}\text { Diversity } \\
0.22 \\
\text { ic Diversity } \\
\text { index }\end{array}$} & \multirow{3}{*}{\begin{tabular}{|l} 
TOD \\
Index
\end{tabular}} & \multirow{3}{*}{$\begin{array}{c}\text { TOD } \\
\text { Typology }\end{array}$} \\
\hline Station & Commercial & esident & School & Parking & $\begin{array}{l}\text { Open } \\
\text { space }\end{array}$ & Hospital & $\begin{array}{l}\text { Density } \\
\text { inder }\end{array}$ & Population & n FAR & $B C R$ & $\begin{array}{l}\text { Economic } \\
\text { index }\end{array}$ & & & \\
\hline Weight & 0.32 & 0.27 & 0.13 & 0.12 & 0.09 & 0.08 & & 0.48 & 0.31 & 0.21 & & & & \\
\hline Univ Indonesia & 0.01 & 0.35 & 0.00 & 0.05 & 0.36 & 0.13 & 0.15 & 0.05 & 0.30 & 0.51 & 0.22 & 0.62 & 0.27 & Suburban \\
\hline Pd Cina & 0.13 & 0.37 & 0.00 & 0.08 & 0.09 & 0.13 & 0.17 & 0.05 & 0.55 & & 0.31 & & 0.27 & \\
\hline Poris & & 0.46 & 0.00 & 0.04 & 0.34 & 0.00 & & & & & & & 0.27 & \\
\hline Rawa Bu & 0.0 & 0.79 & 0.00 & 0.05 & 0.15 & 0.00 & & & & 80.60 & & & 0.29 & 5 \\
\hline Sudimara & & 91 & 0.05 & 0.05 & 0.08 & 0 & & & & & & & 0.31 & 5 \\
\hline Cilebut & & 0 & 0.00 & 0.04 & 0.23 & & & & & & & & 0.31 & \\
\hline Depok & & & 0.05 & 0.05 & 12 & & & & & & & & 0.32 & \\
\hline Pd. Ranji & & & 0.1 & 0 & 18 & & & & & 10.58 & & & 0.32 & \\
\hline Bekasi & & & 0.1 & 0. & 18 & 0. & & & & & & & .33 & \\
\hline & & & 0.0 & 0 & 01 & & & & & & & & & \\
\hline Krani & & & & & 08 & & & & & & & & & \\
\hline Citayan & & & 0.0 & & 14 & & & & & & & & & \\
\hline Serpo & & & & 0 & & & & & & & & & .35 & \\
\hline Univ P. & & & & 0 & & & & & & & & & & \\
\hline & & & & & & & & & & & & & & \\
\hline & & & & & & & & & & & & & & \\
\hline & & & & & & & & & & & & & & \\
\hline Cakung & & & & & & & & & & & & & & \\
\hline Pasar Mi & & & & 0. & 14 & & & & & & & & & \\
\hline & & & & & & & & & & & & & & \\
\hline & & & & & & & & & & & & & & \\
\hline & & & & & & & & & & & & & & \\
\hline & & & & & .11 & & & & & & & & & \\
\hline & & & & & & & & & 0.74 & & & & & \\
\hline & & & & & & & & & & & & & & \\
\hline & & & & & & & & & & & & & & \\
\hline Kran & & & & & & & & & & & & & & \\
\hline Buar & & & & & & & & & & & & & & \\
\hline & & & & & & & & & & & & & & \\
\hline Bogg & & & & & & & & & & & & & & \\
\hline & & & & & & & & & & & & & & \\
\hline & & & & & & & & & & & & & & \\
\hline & & & & 0 & & & & & & & & & & \\
\hline & & & & 0 & & & & & & & & & & \\
\hline & & & & 0 & 0.09 & & & & & & & & & \\
\hline Pesin & & & & 0 & 0.13 & & & & & & & & & \\
\hline $\begin{array}{l}\text { Dukk } \\
\text { Klen }\end{array}$ & & & & & & & & & & & & & & \\
\hline $\begin{array}{l}\text { Kelen } \\
\text { Pasa }\end{array}$ & & & & 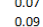 & 0.05 & & & & & & & & & \\
\hline & & & & 80 & 0.06 & & & & & & & & & \\
\hline & & & & 80 & & & & & & & & & & \\
\hline & & & & 每 & & 0 & & & & & & & & \\
\hline & & & & $\begin{array}{l}0 \\
0 \\
0\end{array}$ & & 0 & & & & & & & & \\
\hline & & & 0.3 & 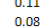 & & & & & & & & & & \\
\hline & & & & & & & & & & & & & & \\
\hline & & & & & 0.13 & & & & & & & & & \\
\hline & & & $\begin{array}{l}0.16 \\
0.08\end{array}$ & 0 & $\begin{array}{l}0.06 \\
0.12\end{array}$ & . & & & & $\begin{array}{l}50.57 \\
20.53\end{array}$ & & & $\begin{array}{l}0.47 \\
0.48\end{array}$ & \\
\hline & & & 0.10 & 0.08 & 0.08 & 0.88 & & & & & & & .48 & \\
\hline & & & & & & & & & & & & & & \\
\hline & & & & & & & & & & & & & & \\
\hline & & & & & & & & & & & & & & \\
\hline & & & & & & & & & & & & & & \\
\hline & & & & & & & & & & & & & & \\
\hline & & & & & & & & & & & & & & \\
\hline
\end{tabular}

The implementation of TOD typology into the transport planning in JMR is depicted in Fig. 10. The figure shows the difference in each station based on TOD typology, where the green color indicates the Urban TOD type, the blue indicates Suburban TOD and the yellow indicates Regional TOD.

\subsection{Policy Implication of TOD Typology in Macro Level}

Determination of TOD area is based on consideration of the transportation system and land use (Table 5). TOD development can be done with the following policies: First, Redevelopment site, which is revitalized with the provision of new facilities and functions equipped with an arrangement and utilization area around TOD station. Second, The development site, i.e. development on vacant land on the radius of TOD area. Third, New growth area, i.e. opening of new areas wide and generally located in the periphery border area. All TOD development policies can be used in combination, complementary to the situation and conditions in the field.

\subsection{Planning Regulations of TOD Typology in Micro Level}

Planning TOD is proposed for mixed housing and commercial lands. It planned to maximize access to public transport for encouraging the use of public transport modes.
Allocation of land around station is developed with difference of density. Fig. 11 shows the TOD zonation in detail based on the distance from the station as the center point.

\subsection{Location of Station}

Sudirman station is a railway station located at east side of main road in central of Jakarta. Depok station located in Depok city and Bojonggede station located in Bogor regency. All station is the crowded station in the morning and afternoon due to the big number of commuters (Fig. 12).

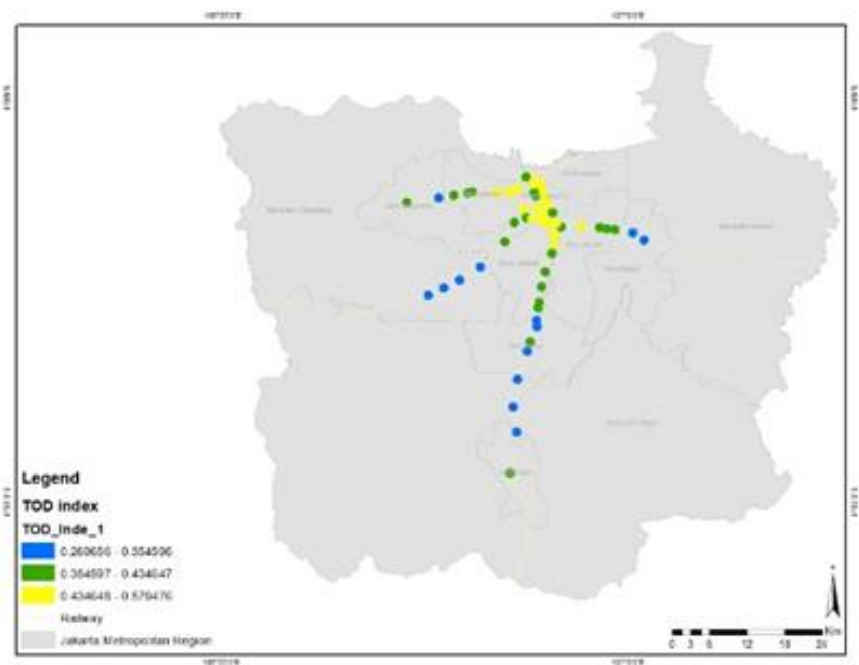

Actual TOD means an existing condition of station (transportation)

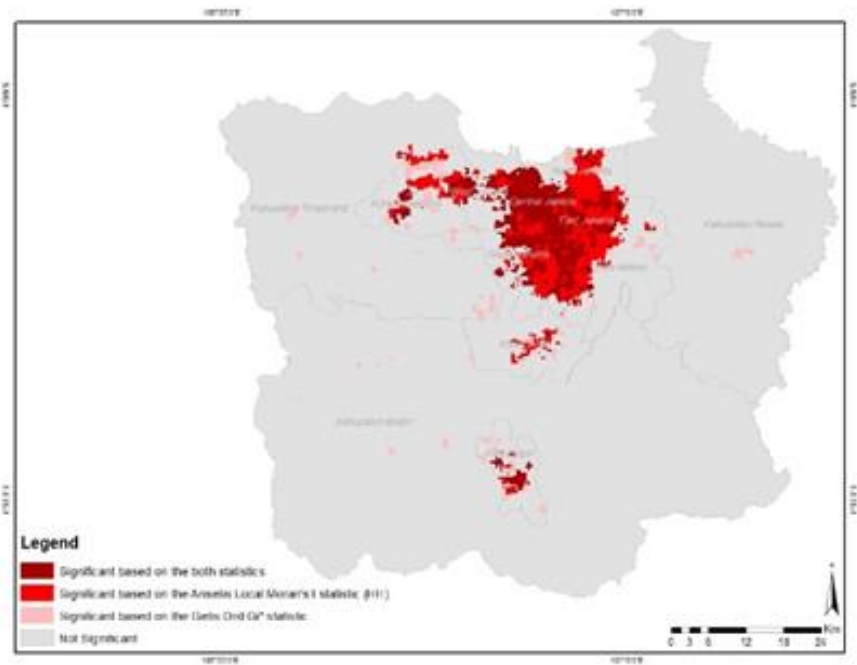

Potential TOD means a potential area for the new station (spatial)

Fig. 8. Actual and potential TOD

\subsection{Promoting TOD Typology by Urban Design for Future}

The aim of promoting TOD typology by urban design for future is to eliminate urban sprawl in the future by changing it into a compact city. Urban design should pay attention to some zoning, such as residential, business, office, public and social facilities so that people can do activities and meet their needs in the area without having to go to the city center. For this design, the TOD is divided based on the following typologies. 


\subsubsection{Regional TOD}

Sudirman station as Regional TOD is a station where the area around the station is the center of government, business and other urban activities so that the existence of the station is not just as a stopover place from the commuter but as a mass movement of citizens. This Regional TOD creates synergies between communities in the JMR and the surrounding environment also synergies between commuters and local people. The aim of Sudirman station planning is to create a world-class integrated transport system with integrated land use, transportation modes and transit nodes. Sudirman station as Regional TOD links the transit function of urban areas and the development of surrounding areas based on land use and facility functions.

Regional TOD has a mixture of land use with a high-rise building and it is serviced with a variety of modes of transportation within a network. In addition, the Regional TOD has a thematic land use, mixed with having a tendency towards distinct functions. The maximization of Regional TOD design as a transit center can change the dynamics of public transport in JMR. The intervention in this area is not only planned as a transit point, but also a center filled with mixed-use buildings with comfortable surroundings (Table 6). That way will attract more passenger train enthusiasts. conversely, this causes the use of private vehicles to be reduced (Table 7).

\subsubsection{Urban TOD}

Depok station is a type of urban TOD with service scale of all areas of Depok city, which are on the main circulation path of the city like bus stops, markets and train stations. Urban TOD of Depok station at a medium-intensity mixed-use location and integrate between trains with buses and microbuses serving city dwellers. Design of Urban TOD not only on its function as a transit point, but also consider the convenience of its users.

Urban TOD Depok station was developed along with commercial functions that have medium intensity, blind block, and medium-intensity residence, as can be seen in Table 8 . This was carried out in accordance with the character of the environment.

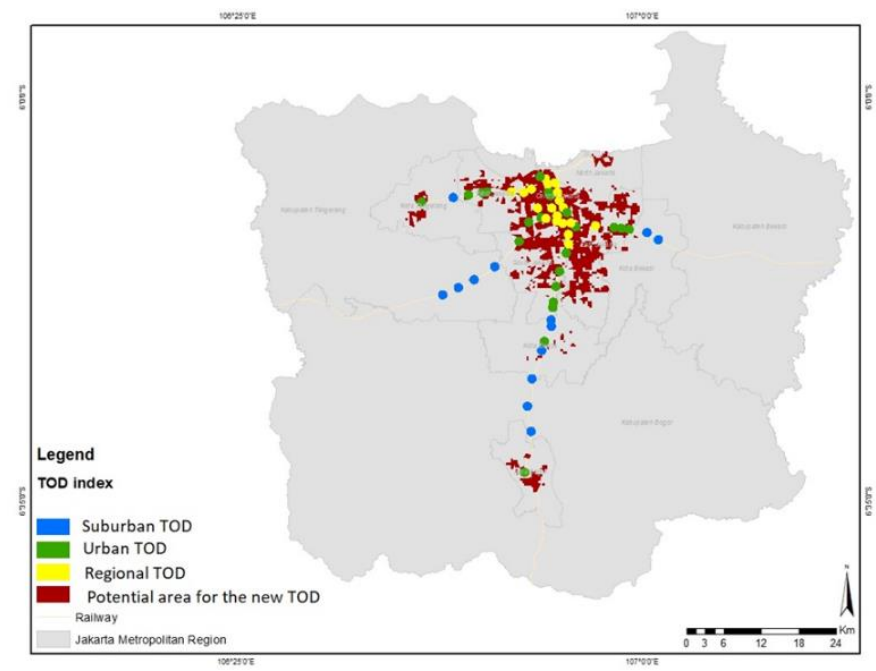

Fig. 9. The typology of integrated TOD spatial model
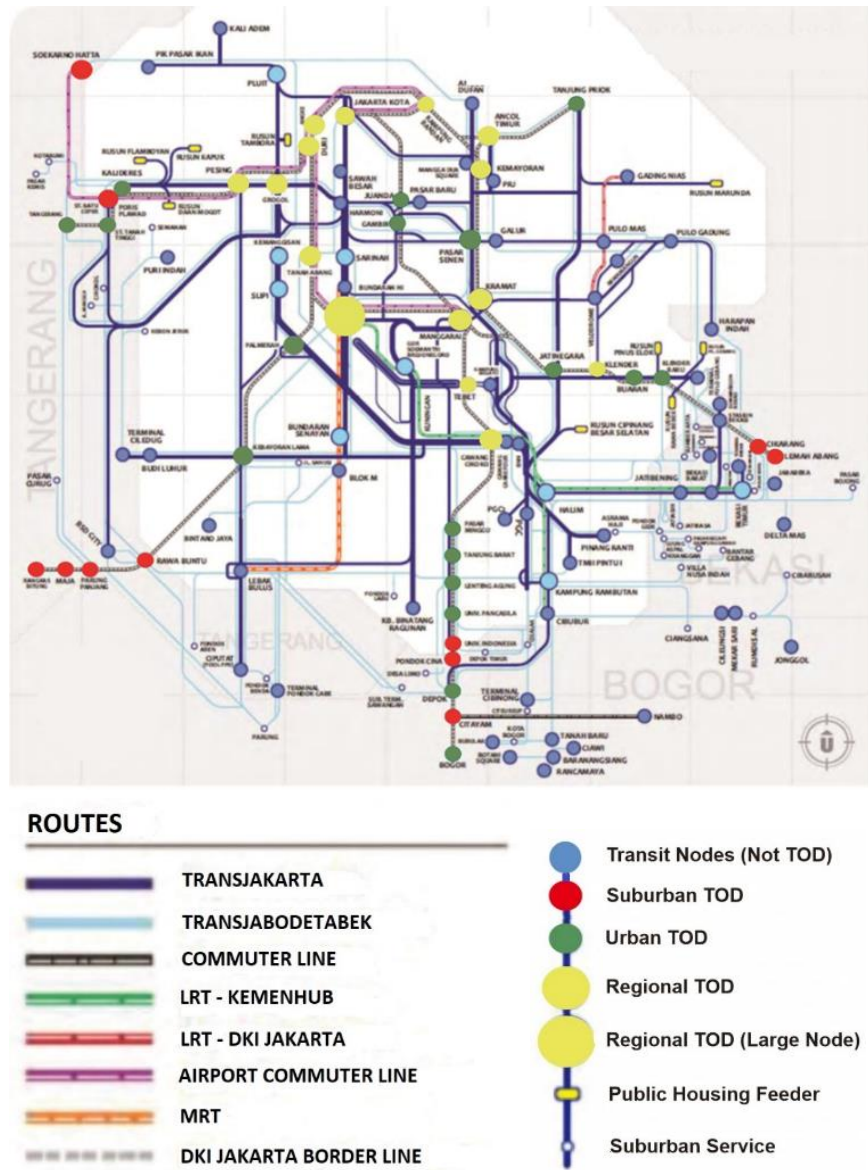

Fig. 10. Transport planning of JMR equipped by TOD typology

Table 5. Policy implication

\begin{tabular}{|c|c|c|c|c|}
\hline & \multicolumn{3}{|c|}{ TOD typology } \\
\hline & & Regional & Urban & Suburban \\
\hline \multirow{2}{*}{ 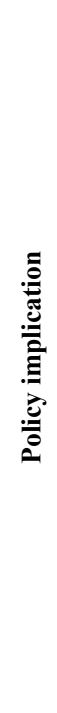 } & Land use & $\begin{array}{l}\text { - Domination } \\
\text { of office area } \\
\text { - Development } \\
\text { of strategic } \\
\text { areas of } \\
\text { economic } \\
\text { interest } \\
\text { Provision of } \\
\text { bridges to } \\
\text { residential }\end{array}$ & $\begin{array}{l}\text { - Mixing } \\
\text { residential } \\
\text { and office } \\
\text { areas } \\
\text { - Construction } \\
\text { of primary } \\
\text { activity } \\
\text { centres } \\
\text { - Development } \\
\text { of high- } \\
\text { density office }\end{array}$ & $\begin{array}{l}\text { - Domination } \\
\text { of residential } \\
\text { area } \\
\text { - Development } \\
\text { of a } \\
\text { secondary } \\
\text { activity } \\
\text { centre } \\
\text { - Construction } \\
\text { of flats and } \\
\text { green spaces }\end{array}$ \\
\hline & Transport & $\begin{array}{l}\text { - Optimization } \\
\text { of mass } \\
\text { transportation } \\
\text { services } \\
\text { between } \\
\text { modes } \\
\text { - Operation of } \\
\text { the airport } \\
\text { train }\end{array}$ & $\begin{array}{l}\text { - Provision of } \\
\text { pedestrian } \\
\text { paths } \\
\text { between } \\
\text { stations or } \\
\text { bus stops } \\
\text { - Organizing } \\
\text { park and ride } \\
\text { - Improving } \\
\text { commuter } \\
\text { rail service }\end{array}$ & $\begin{array}{l}\text { - Changes to } \\
\text { local rail } \\
\text { service } \\
\text { - Extension of } \\
\text { rail service } \\
\text { - Improving } \\
\text { service } \\
\text { quality of } \\
\text { pedestrian } \\
\text { and bike }\end{array}$ \\
\hline
\end{tabular}

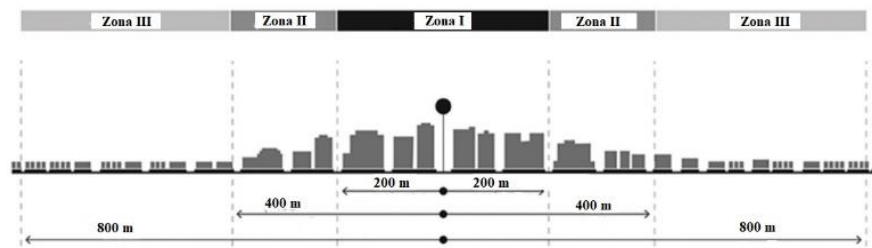

Fig. 11. TOD zonation 
Table 6. Intervention for Regional TOD

\begin{tabular}{lcccc}
\hline Existing & $\begin{array}{c}\text { Maximum } \\
\text { FAR }\end{array}$ & $\begin{array}{c}\text { Cover } \\
\text { area }\end{array}$ & $\begin{array}{c}\text { Number } \\
\text { of floors }\end{array}$ & Land use \\
\hline Intervention & 10 & $70 \%$ & $10^{\text {st }}$ floor & $\begin{array}{c}\text { commercial, } \\
\text { office, residential }\end{array}$ \\
\hline
\end{tabular}

Table 7. General regulations of TOD typology

\begin{tabular}{|c|c|c|c|c|c|c|c|c|c|}
\hline & \multicolumn{9}{|c|}{ TOD typology } \\
\hline & \multicolumn{3}{|c|}{ Regional } & \multicolumn{3}{|c|}{ Urban } & \multicolumn{3}{|c|}{ Suburban } \\
\hline & $200 \mathrm{~m}$ & $400 \mathrm{~m}$ & $800 \mathrm{~m}$ & $200 \mathrm{~m}$ & $400 \mathrm{~m}$ & $800 \mathrm{~m}$ & $200 \mathrm{~m}$ & $400 \mathrm{~m}$ & $800 \mathrm{~m}$ \\
\hline \multicolumn{10}{|c|}{ Sustainability requirement } \\
\hline $\begin{array}{l}\text { Targeted rank } \\
\text { of LEED }\end{array}$ & $\begin{array}{c}\text { Platinu } \\
\mathrm{m}\end{array}$ & Gold & $\begin{array}{c}\text { Silve } \\
\mathrm{r}\end{array}$ & Gold & Gold & $\begin{array}{c}\text { Silve } \\
\mathrm{r}\end{array}$ & Gold & $\begin{array}{c}\text { Silve } \\
\mathrm{r}\end{array}$ & $\begin{array}{c}\text { Bron } \\
\text { ze }\end{array}$ \\
\hline \multicolumn{10}{|c|}{ Connectivity requirement } \\
\hline $\begin{array}{l}\text { Maximum } \\
\text { length of land } \\
\text { (m) }\end{array}$ & $75-120$ & $\begin{array}{l}75- \\
150\end{array}$ & $\begin{array}{l}120- \\
150\end{array}$ & $\begin{array}{l}75- \\
120\end{array}$ & $\begin{array}{l}120- \\
150\end{array}$ & $\begin{array}{l}150- \\
180\end{array}$ & $\begin{array}{l}120- \\
150\end{array}$ & $\begin{array}{l}150- \\
180\end{array}$ & $\begin{array}{l}120- \\
240\end{array}$ \\
\hline \multicolumn{10}{|c|}{ Open space requirement } \\
\hline $\begin{array}{l}\text { Width of } \\
\text { pedestrian } \\
\text { paths }(\mathrm{m})\end{array}$ & $9-+14$ & $\begin{array}{l}7.5- \\
+10\end{array}$ & $6-+8$ & $\begin{array}{c}8- \\
+12\end{array}$ & $\begin{array}{c}6- \\
+10\end{array}$ & $6+8$ & $\begin{array}{c}6- \\
+10\end{array}$ & $6-+8$ & $5+8$ \\
\hline $\begin{array}{l}\text { Ratio of public } \\
\text { open spaces }\end{array}$ & $10-15 \%$ & $\begin{array}{l}10- \\
15 \%\end{array}$ & $\begin{array}{l}10- \\
15 \%\end{array}$ & $\begin{array}{l}10- \\
20 \%\end{array}$ & $\begin{array}{l}10- \\
20 \%\end{array}$ & $\begin{array}{c}5- \\
15 \%\end{array}$ & $\begin{array}{l}10- \\
20 \%\end{array}$ & $\begin{array}{l}10- \\
20 \%\end{array}$ & $\begin{array}{l}10- \\
20 \%\end{array}$ \\
\hline \multicolumn{10}{|c|}{ Building regulation } \\
\hline FAR & 5-10 & $3.5-6$ & $\begin{array}{l}1.2- \\
1.8\end{array}$ & $3-5$ & $2-4$ & $\begin{array}{l}1.2- \\
1.8\end{array}$ & $2-4$ & $1.5-2$ & $\begin{array}{l}1.2- \\
1.8\end{array}$ \\
\hline $\begin{array}{l}\text { Maximum } \\
\text { BCR }\end{array}$ & $50 \%$ & $50 \%$ & $50 \%$ & $50 \%$ & $50 \%$ & $50 \%$ & $50 \%$ & $50 \%$ & $50 \%$ \\
\hline $\begin{array}{l}\text { Maximum } \\
\text { number of } \\
\text { floors }\end{array}$ & $\begin{array}{c}\text { No } \\
\text { control }\end{array}$ & $\begin{array}{c}\text { No } \\
\text { contr } \\
\text { ol }\end{array}$ & $\begin{array}{c}\text { No } \\
\text { contr } \\
\text { ol }\end{array}$ & 10 & 8 & 3 & 8 & 4 & 3 \\
\hline $\begin{array}{l}\text { Active } \\
\text { facades* }\end{array}$ & $\begin{array}{c}70- \\
100 \%\end{array}$ & $\begin{array}{l}65- \\
90 \%\end{array}$ & $\begin{array}{c}50- \\
80 \%\end{array}$ & $\begin{array}{c}60- \\
100 \%\end{array}$ & $\begin{array}{c}50- \\
80 \%\end{array}$ & $\begin{array}{l}<50 \\
\%\end{array}$ & $\begin{array}{l}60- \\
90 \%\end{array}$ & $\begin{array}{l}60- \\
90 \%\end{array}$ & $\begin{array}{l}<40 \\
\%\end{array}$ \\
\hline Land use & & & & & & & & & \\
\hline $\begin{array}{l}\text { Ratio of } \\
\text { residential }\end{array}$ & $20 \%$ & $30 \%$ & $40 \%$ & $45 \%$ & $50 \%$ & $70 \%$ & $60 \%$ & $75 \%$ & $85 \%$ \\
\hline \multicolumn{10}{|l|}{ Parking } \\
\hline $\begin{array}{l}\text { Nature of } \\
\text { parking }\end{array}$ & $\begin{array}{l}\text { Undergr } \\
\text { ound/mu } \\
\text { lti floor }\end{array}$ & $\begin{array}{c}\text { Unde } \\
\mathrm{rgrou} \\
\mathrm{nd} / \mathrm{m} \\
\text { ulti } \\
\text { floor }\end{array}$ & $\begin{array}{c}\text { Unde } \\
\text { rgrou } \\
\text { nd/m } / \mathrm{m} \\
\text { ulti } \\
\text { floor }\end{array}$ & $\begin{array}{c}\text { Unde } \\
\mathrm{rgrou} \\
\mathrm{nd} / \mathrm{m} \\
\text { ulti } \\
\text { floor }\end{array}$ & $\begin{array}{c}\text { Unde } \\
\mathrm{rgrou} \\
\mathrm{nd} / \mathrm{m} \\
\text { ulti } \\
\text { floor }\end{array}$ & $\begin{array}{c}\text { Over } \\
\text { groun } \\
\mathrm{d}\end{array}$ & $\begin{array}{l}\text { Unde } \\
\text { rgrou } \\
\text { nd }\end{array}$ & $\begin{array}{l}\text { Multi } \\
\text { floor }\end{array}$ & $\begin{array}{l}\text { Super } \\
\text { ficial }\end{array}$ \\
\hline $\begin{array}{l}\text { For every } 100 \\
\mathrm{~m}^{2} \text { out of the } \\
\text { total built up } \\
\text { area }\end{array}$ & $\begin{array}{l}1.18- \\
1.66\end{array}$ & $\begin{array}{l}1.56- \\
1.79\end{array}$ & $\begin{array}{l}1.44- \\
1.65\end{array}$ & $\begin{array}{l}1.15- \\
1.51\end{array}$ & $\begin{array}{l}1.43- \\
1.59\end{array}$ & $\begin{array}{l}1.23- \\
1.37\end{array}$ & $\begin{array}{l}1.30- \\
1.46\end{array}$ & $\begin{array}{l}1.14- \\
1.27\end{array}$ & $\begin{array}{r}0.94- \\
1.06\end{array}$ \\
\hline
\end{tabular}

Table 8. Intervention for urban TOD

\begin{tabular}{lcccc}
\hline Existing & $\begin{array}{c}\text { Maximum } \\
\text { FAR }\end{array}$ & $\begin{array}{c}\text { Cover } \\
\text { area }\end{array}$ & $\begin{array}{c}\text { Number of } \\
\text { floors }\end{array}$ & Land use \\
\hline Intervention & 1 & $50 \%$ & $5^{\text {nd }}$ floor & $\begin{array}{c}\text { commercial, } \\
\text { residential }\end{array}$ \\
\hline
\end{tabular}

Table 9. Intervention for Suburban TOD

\begin{tabular}{lcccc}
\hline & $\begin{array}{c}\text { Maximum } \\
\text { FAR }\end{array}$ & $\begin{array}{c}\text { Cover } \\
\text { area }\end{array}$ & $\begin{array}{c}\text { Number of } \\
\text { floors }\end{array}$ & Land use \\
\hline Existing & $1.2-2$ & $40 \%$ & $2^{\text {nd }}$ floor & residential \\
\hline Intervention & 4 & $50 \%$ & $10^{\text {st }}$ floor & $\begin{array}{c}\text { commercial, } \\
\text { residential }\end{array}$ \\
\hline
\end{tabular}

\subsubsection{Suburban TOD}

Bojonggede station is Suburban TOD located in the middle of a residential area and has public transportation trails with affordable distance by walking. Suburban TOD has a highintensity residential environment with public facilities and green open spaces, providing easy access to passengers.

Bojonggede station design seeks to awaken the building's existence for economic revitalization and environmental improvement through the density of commuter traffic that uses it. The design of this TOD focuses on incorporating the principles of environmental justice into planning. The area has special characteristics due to its occupants are dominated by commuter settlers who working in downtown and away from their settlements. But slowly the area around the station is built also a commercial area to serve the population but by creating a pedestrian-friendly environment (Table 9).

\section{Conclusion}

There are differences in the TOD typology in the Metropolitan Jakarta Region where the Regional TOD is in the downtown, Urban TOD is around the city, and the Suburban TOD is spread outside the city center. This typology is integrated into urban planning so that this TOD model guide transportation planning of JMR. Various policies and designs are expected to make JMR transportation become sustainable.

\section{References}

1. H. M. Taki, M. M. H. Maatouk, E. M. Qurnfulah, M. O. Aljoufie, Planning TOD with land use and transport integration: A review, J. Geosci. Eng. Environ. Technol. 2 (2017) 84-94.

2. H. M. Taki, Slum revitalizing plan of Baghdadiyah by spatial re-modeling configuration, Geoplanning J. Geomatics Plan. 4 (2017) 191-196.

3. S., Putman, Policy analysis of transportation and land use (RLE: The City) in Integrated Urban Models, Taylor and Francis Group, London, 2013.

4. H. Taki, M. Lubis, Modeling accessibility of community facilities using GIS: case study of Depok City, Indonesia, J. Appl. Geospatial Inf. 1 (2017) 36-43.

5. H. Hasibuan, T. Soemardi, The role of transit oriented development in constructing urban environment sustainability, the case of Jabodetabek, Indonesia. Procedia Environ. Sci. 20 (2014) 62-631.

6. H. M. Taki, M. M. H. Maatouk, R. Koestoer and S. Moersidik, Spatial planning for potential green TOD using suitability analysis at the metropolitan region scale, IOP Conf. Ser. Earth Environ. Sci. 160 (2018) 012020.

7. Alvinsyah and E. Hadian, A demand and capacity analysis on bus semirapid transit network (Case: Jabodetabek public transport network), MATEC Web Conf. 181 (2018) 10001.

8. H. M. Taki, M. M. H. Maatouk, E. M. Qurnfulah, S. Antoni, Land Suitability Assessment for the Potential Location of Transit Oriented Development (TOD). In: Smart Societies, Infrastructure, Technologies and Applications. Springer, Cham, 2018, pp. 357-359.

9. Taki, H., Geoscience, M.M.-J. of, Engineering, U., 2018, U.: Spatial Statistical Analysis for Potential Transit Oriented Development (TOD) in Jakarta Metropolitan Region, J. Geosci. Eng. Env. Tech. 3 (2018) 47-56.

10. G. Tanuwidjaja, B. G. Chang, Green Infrastructure Concept for JABODETABEKJUR Metropolitan Area. IOP Conf. Ser. Earth Environ. Sci. 79 (2017) 012024.

11. H. Sung, J. T. Oh, Transit-oriented development in a high-density city: Identifying its association with transit ridership in Seoul, Korea, Cities 28 (2011) 70-82.

12. D. S. Vale, Transit-oriented development, integration of land use and transport, and pedestrian accessibility: Combining node-place model with pedestrian shed ratio to evaluate and classify station areas in Lisbon, J. Transp. Geogr. 45 (2015) 70-80.

13. T. Mafame, Transit-oriented development (TOD) as a facilitator for urban development integration: Case study: Du Toit train station precinct, Master Thesis, Stellenbosch University, South Africa, 2017.

14. R. Cervero, C. Sullivan, Green TODs: Marrying transit-oriented development and green urbanism. Int. J. Sustain. Dev. World Ecol. 18 (2011) 210-218.

15. N. L. A. Widyahari, P. N. Indradjati, The potential of transit-oriented development (tod) and its opportunity in Bandung metropolitan area. Procedia Environ. Sci. 28 (2015) 474-482.

16. T. Jaiswal, GIS based suitability analysis for transit oriented development opportunities: The case of eastern corridor in the Cincinnati metropolitan area, PhD Thesis, University of Cincinnati, USA, 2008.

17. H. M. Taki, M. M. H. Maatouk, E. M. Qurnfulah, Re-Assessing TOD index in Jakarta metropolitan region (JMR), J. Appl. Geospatial Inf. 1(2017) 2635. 